\title{
Is International Trade Reduces the External Conflicts? Case Study of Pakistan and India
}

\section{Ayesha Kiran*}

Department of Economics, National University of Science and Technology Islamabad, Pakistan

\begin{abstract}
This study shows the importance of trade to create the peace and stability among the Pakistan and India. Pakistan-India trade relations, trade restrictions, benefits of bilateral trade among them and benefits obtained through trade are argued in this paper. Trade is a tool of achieving peace through interdependence and attaining the mutual economic benefits. Pakistan-India negotiations on border disputes and purpose of establishing the peace are critically important for both nations. Trade is soft and positive way to reduce the conflicts. Openness to international trade is significant driver of liberal peace.
\end{abstract}

Keywords: International trade; External conflicts

\section{Introduction}

The border disputes negatively affect the trade among the neighboring countries. Many of countries resources are transfer to safeguard their borders. Trade among countries reduces the chances of war because of mutual interdependence is increasing. The opportunity cost of war is adverse economic growth. It is beneficial for countries to attain the economic gain from trade rather than having war and conflicts. Countries adopt the liberalize trade policies for getting benefits from international transaction and through this reduce the adverse effects. Such powerful policies are adopted by countries that not only regulate their trade transactions but also get the safeguard their interests.

Globalization changes the international environment. Interdependence among the countries increases and it reduces the mutual conflicts. Even though China and USA also trade with each other's for their own benefit of interest. Pakistan and India are neighboring countries, their trade relations are not at good pace. In recent years different strategies are adopted by both countries to reduce their conflicts. Conflicts are reduced by both countries political, social and military cooperation. Foreign trade policy is important indicator of determining of bilateral trade relations among the India and Pakistan. Peace between them is not only important for them but also for region. By opening the trade and investment various welfare gains are attained by the nations. Trade return from neighboring country is high as compared to far country. Due to conflicts trade diversion takes place.

Pakistan and India get more from trade rather than from war. Trade reduces the chances of war. Through trade contact between the countries is increases; they harmonized the trade policies to reduce the tension among them. Through trade liberalization not only specialization in goods takes place but also provide foreign goods to local consumers. Through conflicts hostilities increase and marketable relations among the countries are badly affected. Trade liberalization fosters the economic growth, efficient allocation of resources and both consumers and producers get the benefit. Exchange of goods among the countries, economic benefit is more than causes of conflicts. Trade and political disputes creates the costly hostilities and increase the political- military adverse relationship among the countries. More trade flows not only provides the economic benefits but also reduces the military conflicts.

When countries are in more interdependence, the chances of war among them are automatically minimize. In the passing years, India and Pakistan are focusing in promoting the peace in region by improving the trade between them. Trade is not strong between India and Pakistan. Political issues, wars, modification in relations after war creating the hurdles for economic cooperation and both countries are enable to make the future expectations with each other. Although there are inconsistencies, that are present in foreign policies regarding the trade. Pakistan and India has common border, they have trade potential more than tenfold of current trade scenario.

Though trade liberalization the economic problem and conflicts are resolved between India and Pakistan. Deteriorating economic growth is settled through trade. Trade between India and Pakistan not only provides the Pakistan's market access to India, it easily gets the market access of Central Asia and Middle East via Pakistan's border. Both countries gets the benefits of natural resources of Central Asia by making combine agreements. More formal trade reduced the smuggling and border terrorism though illegal crossing.

\section{Trade Flow between India and Pakistan}

India trade share in Pakistan is less than 3\% and Pakistan trade share in India is less than $2 \%$. Pakistan import from India rise after the 2009 as compare to India import from Pakistan. Trade volume is not enough between India and Pakistan because less amount of trade takes places (Table 1 and Figure 1).

The factor of war, political and military conflicts hampered the trade relationship among the India and Pakistan. The foreign policy between India and Pakistan is important factor and lots of hurdles is present in Most Favourite Nation provision. Although both countries gets benefited from bilateral trade, but inconsistency in relations

*Corresponding author: Ayesha Kiran, Department of Economics, Nationa University of Science and Technology Islamabad, Pakistan, Tel: +92-51-90856878 E-mail: ayesha.kiran17@gmail.com

Received January 01, 2018; Accepted January 12, 2018; Published January 16 2018

Citation: Kiran A (2018) Is International Trade Reduces the External Conflicts? Case Study of Pakistan and India. Int J Econ Manag Sci 7: 504. doi: 10.4172/2162 6359.1000504

Copyright: (c) 2018 Kiran A. This is an open-access article distributed under the terms of the Creative Commons Attribution License, which permits unrestricted use, distribution, and reproduction in any medium, provided the original author and source are credited. 
reduces the welfare gain of trade. Pakistan trading with India is less than $\$ 1$ billion and $\$ 2$ billion at the time of 2005 and 2012.

\section{International experience}

After the World War 2, economic condition of Europe found to be demolished. Power and authority is main cause of war. Countries are indulged in to influence the other nation and take control of others recourses. When Europe countries badly suffer, Hitler lost its war, British has no money and it became bankrupt and France had no enough labors to do the work in labor market. France unable to control the Germany, which is rich in resources of coal, better industry and then they anxiously started to stop the German to use their resources for war. In 1953, European Steel and Coal Community were established and Belgium, Germany, France, Italy, Luxembourg and Netherland were included. These countries decided to start free trade zone for limited goods and resources. After this success, European Economic Community was founded in 1958. Denmark, Ireland, the United Kingdom, Portugal and Spain joined this European Economic Community between 1958 and 1986. The countries have mutual interest of economics prosperity so they started effort for cooperation

\begin{tabular}{|c|c|c|c|c|}
\hline Years & $\begin{array}{c}\text { Indian imports-Pakistani } \\
\text { exports }\end{array}$ & $\begin{array}{c}\text { Indian exports-Pakistani } \\
\text { imports }\end{array}$ & BOT & VOT \\
\hline 1998 & 188 & 135 & 53 & 323 \\
\hline 1999 & 96 & 115 & -19 & 211 \\
\hline 2000 & 62 & 171 & -109 & 233 \\
\hline 2001 & 70 & 230 & -160 & 300 \\
\hline 2002 & 50 & 177 & -127 & 227 \\
\hline 2003 & 84 & 226 & -142 & 310 \\
\hline 2004 & 158 & 454 & -296 & 612 \\
\hline 2005 & 337 & 577 & -240 & 914 \\
\hline 2006 & 327 & 1115 & -788 & 1442 \\
\hline 2007 & 292 & 1266 & -974 & 1558 \\
\hline 2008 & 355 & 1691 & -1336 & 2046 \\
\hline 2009 & 235 & 1080 & -845 & 1315 \\
\hline 2010 & 275 & 1560 & -1285 & 1835 \\
\hline 2011 & 273 & 1607 & -1334 & 1880 \\
\hline 2012 & 348 & 1573 & -1225 & 1921 \\
\hline 2013 & 542 & 2065 & -1523 & 2607 \\
\hline 2014 & 428 & 2031 & -1603 & 2460 \\
\hline
\end{tabular}

Source: IMF direction of trade statistics (2014).

Table 1: Pakistan-India trade flows (1998-2014). with each other and establish the treaty EUROPEON UNION. After the establishment of EU, countries create peace with stability.

ASEAN (Association of South East Asian Nations) countries have high economic growth and cooperation. In 1975, Vietnam attacked Cambodia and Thailand support the America in the Vietnam War. Thailand and Laos had conflicts and war in 1988.Now these ASEAN countries cooperate with each other through regional integration. Northern Ireland and United Kingdom has disputes with each other. After 30 years of conflicts, Irish Army stopped the military conflicts, settled the disputes and agreed not to done any terrorist activity in either in their own country and in United Kingdom. Singapore and Malaysia have not better political relations but they settled their disputes for economic consideration. Stakeholder's formation helps to reduce the tension and resolve their disagreements.

\section{Objective of Study}

The objective of study is to explain "the trade potential between the India and Pakistan promotes the peace and stability. Bilateral trade helps to reduce external conflicts and chances of war."

\section{Literature Review}

It is argued by liberal theorist that international trade is important component of creating peace among the countries and it also reduced the war. Due to increase in trade independence among the countries creates corporation and gets the gain from trade. Countries has more opportunity cost for war and conflicts. Conflicts go to decline with more economic interdependence among the countries. According to view of liberal theorists, trade is important for the promotion of peace. As conflicts between the countries reason of welfare loss from reduction in trade. Countries involved in more trade and interrelationship decline the conflicts. Through fostering the trade, countries influence each other through culture and social behavior. According to Keynes, trade is tool that reduces the conflicts and creates peace among the rival countries.

Cali and Miaari [1] analyzed the impact of price shock on commodities. Data used in time period of 1990's of war in different areas of Palestine. The trade impact on trade was determined particularly on exports. The results showed that increased in exports reduces the conflicts in localities. Exports of Palestine increased by USD 10 million and increased the employment opportunities. Palestine Israel trade conflicts reduced through interacting the local institution for increasing the trade opportunities among them.

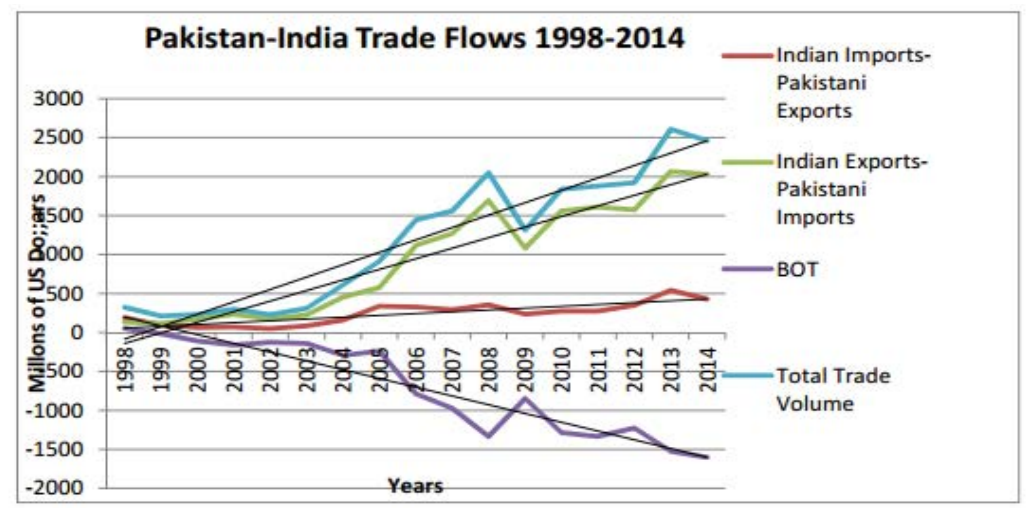

Source: Author's estimation and calculation

Figure 1: Pakistan-India trade flow 1998-2014. 
Martin et al. [2] examined the impact of war on trade. Trade is negatively affected by military conflicts. Data was used from 1950 to 2000 era of military conflicts. Results showed that by making the regional integration and agreements not only increases the trade but creates peace due interdependence among the countries. Conflicts are reduced by globalization in trade.

Lee and Pyun [3] investigate the impact of conflict on trade volume. Panel data had been used from 1950 to 2000 . The results showed that peace among the countries obtained through the globalization and integration. Military conflicts were reduced and bilateral and unilateral trade showed the positive impact on peace among close geographic countries. Economic and political benefits are obtained through integration.

Brutger and Wright [4] examined that international relations were affected through the trade conflicts and their impact on peace among the countries. The data on conflict used from 1950 to 1990. Results showed that neighboring countries disputes creates the trade diversion among the countries and trade takes placed with high cost countries. It effects the country's own economic growth and countries suffered the opportunity cost from trade diversion.

Sab [5] examined the impact of conflicts of Middle East with their near countries in their geographic region. Finding of results showed that economic growth is hampered due to conflicts, fiscal deficit and negatively declined the reserves. After the conflicts economic condition badly suffered and it is settled by diminishing the conflicts. Institutions play important role for the retrieval of the economic stability after conflict time.

Polachek and Seigile [6] examined that interdependence among the countries reduced the war and conflicts. Social and welfare gain attained through the trade. The result showed that trade creates the peace and causes the capital inflows. Countries with no conflicts easily invite the Foreign Direct Investment in countries. Reduction in trade barriers liberalized the trade and Terms of Trade positively affected.

Taneja et al. [7] investigated that Pakistan and India had trade potential and further could be increased. The trade between both countries increased from $\$ 20$ billion in future and it is 10 times more than current trade. Future export potential estimated as $\$ 16$ billion and future import potential estimated as $\$ 4$ billion.

Khan [8] suggested that trade between Pakistan and India increased in future more than current value. The greater trade between both countries raised the GDP and house hold income. It was optimistic approach that net welfare gain in both countries increased through the trade.

\section{Research and Methodology}

Descriptive research method has been used for analyzing the depth of subject matter. For research secondary data sources is used from different books, research articles and research journals. In this study briefly focus Pakistan India trade relationship and conflicts. Firstly, trade through bilateral trade between India and Pakistan and their informal channels are explained. Secondly, the possibility of peace condition obtained through trade is discussed. In last section conclusion and recommendations are discussed.

\section{Pakistan India trade relationship and conflicts}

After independence, Pakistan exported three fifth to India to its total export and one third of its total import from India (Figure 2).

\section{Pakistan and India trade vs. political and military conflicts}

After being independence state India and Pakistan are in conflict on Kashmir Issue. Both countries claimed that Kashmir is part of their country. This issues lead to war in 1948. Conflicts among them not decreased with passage of time. Devaluation of currency issue between both countries effect the trade. Pakistan did not devalue its currency; India in 1949 devalued its currency and imposes the trade barriers. Bilateral trade goes down after it [9]. In the end of 1949 trade between both countries is stopped and started after 1951.The trade between the countries is declined by $20 \%$. In 1965 due to war, trade level goes to zero percentage and the conflicts at peak at that time. It continued for 17 days. After war, 1966-67 the trade relation between goes better, but trade relationship is limited. As the relations go better, war in 1971 had badly affected the trade relation. Both countries signed the agreement in Shimla in order to solve the disputes regarding the

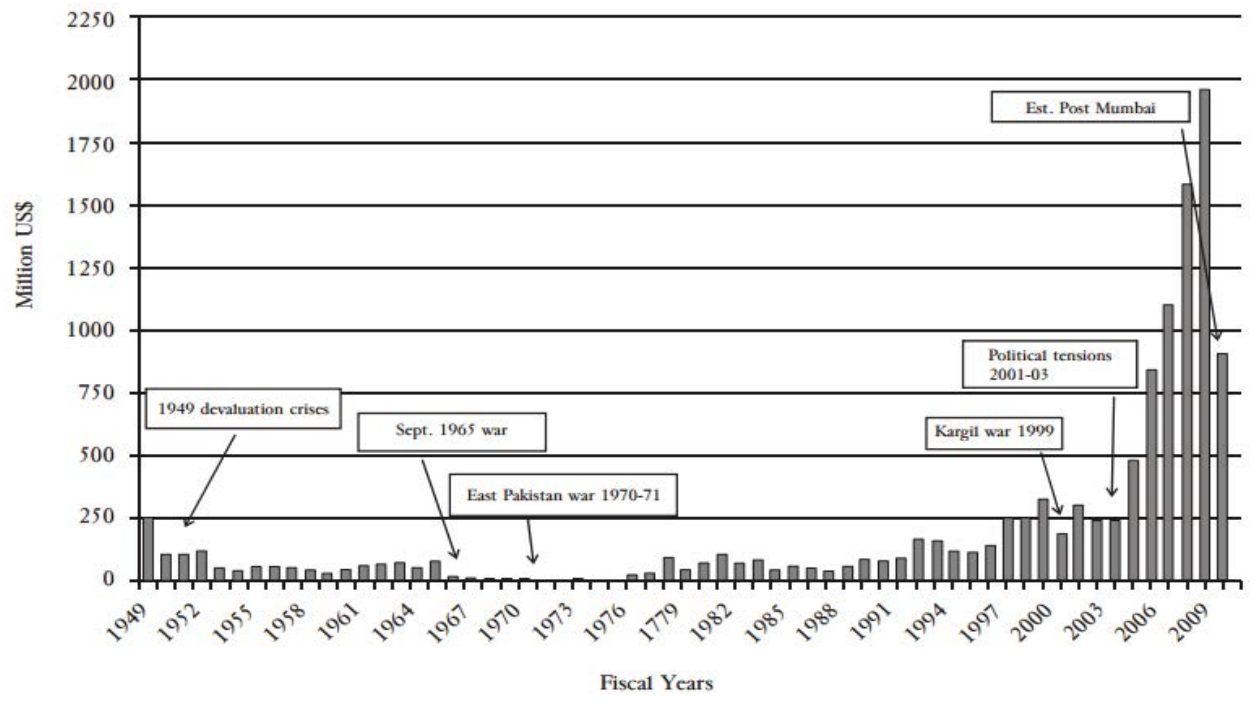

Source: Ministry of Commerce, Government of Pakistan.

Figure 2: Pakistan and India trade vs. Political and military conflicts. 
1971's war. Trade agreement between India and Pakistan signed in 1974 and trade initiative is taken. After couple of dialogues, political relation got progress and started the trade again. In the end of 1970's, both countries made the agreement on railway passageway. In 1980's, Kashmir separatist matter was gone at peak. Pakistan provided not only military support to Kashmir, also gave the political support to them. India is against to Pakistan and argued that Pakistan has provided the training to people for fighting in Kashmir and supported the Kashmir insurgent [10].

In the decade of 1990 s, the trade relations between the countries are going to be better. Indian Prime minister visited the Pakistan and agreement was made to start the bus service between Delhi and Lahore. In this time border conflicts are taken to be set aside and peace and trade was only the motive. The nuclear weapon explosion in 1998 creates the interruption in their relationships, 1999 war make hurdles in trade and Indian parliament attack in 2001 caused the trade conflicts. After this India close its trade with Pakistan till 2001. Major initiative was adopted General Pervaiz Musharaf for promoting peace by signing the Lahore Declaration, but it was not show the progress [11]. The trade relation among them settled after 2002 to some extent. When Indian prime minister visited Pakistan for attending SAARC (South Asian Association for Regional Cooperation) conference in 2004 and dialogue between the both prime ministers is held for making better relation for both political and economic considerations. Reducing the trade barriers, intra bus and truck service in Kashmir are important aspects of this dialogue. Pakistan and India did the agreement on SAFTA (South Asian Free Trade Area) in 2004 and it was started to force by 2006. Due to SAFTA agreement both countries resolved their dispute at political bodies of government. Between 2004 to 2007 dialogues, major intention was to increase the economic activities between both countries. In the end of 2008, both countries ease the visa policy system. At this time bilateral trade goes better between both countries. Mumbai attack in 2008 adverse the relationships, temporary stops the trade relations. After the Mumbai attack, the trade is declined due to political tension. According to Indian Chamber of Commerce and Industry, bilateral trade between both countries decreases by $60 \%$ after the Mumbai Attack. Businessmen in both countries refuse to travel to trading countries.

After the composite dialogues, both countries stated the cooperation regarding the peace and trade. Initially adopted the import substitution policies in end of 1980's and start of 1990's India and Pakistan normalization trade policy and liberalization. From 1980 to 2001 , average tariff has been decline from $70 \%$ to $30 \%$. These reforms by Pakistan take him better position to do bilateral trade or SAFTA and enhance the border trade.

\section{Military spending}

After the 1947 Indo-Pak relations are not at good pace. These countries lost their people lives for fighting with each other's. 4 wars are held between them. From 1998 to 2010 both countries spend more in real term on military. India increases its defense budget in constant dollar from $\$ 20$ billion to $\$ 45$ billion. Pakistan increase little above the 5 billion $\$$ over this time. The share of military spending in GDP has declined in Pakistan and India. India declines its spending from under 5\% to 3\% and Pakistan decline it below 3\%. Spending shifted to social sectors, particularly on health and education sector. This military spending is declined after the mutual cooperation among the both countries (Figure 3) [12]

\section{Bilateral trade between India and Pakistan}

The trade between the India and Pakistan takes place through official, nonofficial, smuggling, and through third countries takes place. After the independence Pakistan's export and import from India's share is 23.6 and $50.6 \%$. It is significantly declined after war in 1948 and it reached at 1.3 and $0.06 \%$ in $1975-76$ respectively. Indian export and import from Pakistan's share 2.2 and 1.1\% in 1950-51 and it further decreased to 0.7 and $0.13 \%$ in 2006-07. Both countries are big economies of South Asia. Bilateral trade between them is much less. Trading Cooperation of Pakistan allowed in 1975 to trade with India and imports 48 products. In early 1980's, private companies also started trade with India.

Pakistan trade with India has normalized after the 2001. Pakistan export cotton, cement and copper to India. Through the dialogue section in 2004, bilateral trade increase between India and Pakistan. Pakistan's export to India has been expand the control nature of trade between them allows limited goods for traded.

By making better trade relations with India Pakistan export to India has increase from \$158 million in 2004 to \$2 billion in 2014. This export value is $0.06 \%$ of total India export. Pakistan has imported

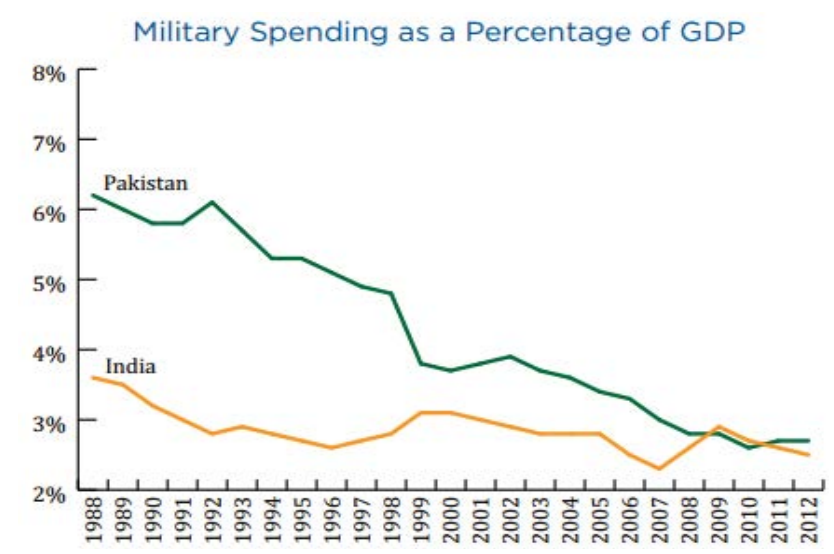

Source: Toby Dalton and Jaclyn Tandler, "Understanding the arms "Race" in South Asia, Carnegie endowment for international peace and SIPRI", September 13, 2012

Figure 3: Military spending as a percentage of GDP. 
the tomatoes, polypropylene and soya bean food items from India. Pakistan import is increase from $\$ 454$ million to $\$ 2.1$ billion and its worth is $0.63 \%$ of its world trade in 2014 .

India trade with SAARC countries raise but relatively low with Pakistan. Pakistan and India reduce their sensitive list that is agreed in SAFTA in 2011. Trade liberalization between India and Pakistan increases after the SAFTA. After the better bilateral trade relationships between both countries trade has been increase from 8 to $10 \%$ between 2008 to 2012. Many empirical studies estimated that reduction in tariff, non-tariff barriers and better logistic deal raised the trade volume by $\$ 8$ to 10 billion. Pakistan realized the importance of trade normalization with India. In 2013 the Pakistan import from India is increase by $33 \%$, while Pakistan export to India is less increased. This is happened due to harmonization of trade policies at government level. In SAFTA, both Pakistan and India are agreed to trade with each other on zero tariffs by 2016 .

Informal trade: The informal trade routes are:

- Mumbai to Dubai to Karachi,

- Dubai to Bander Abbas to Herat to Kabul to Jalabad to Bara,

- India to Singapore to Karachi,

- India to Hong Kong to Karachi.

Formal trade between them is $\$ 2.7$ billion. The informal trade between is more than formal trade and informal trade worth is $\$ 10$ billion [13]. Trade through Dubai to Pakistan from India increase the transportation cost from 1.4 to 1.7 times more than formal trade. India is major exporter of diamond. It did not directly export it to Pakistan. Pakistan exports the diamond via Dubai. This increase the 10 to $15 \%$ import duty. If Pakistan makes direct Import from India it will save $\$ 400$ to $\$ 900$ million annually. Foundry manufactured company trade with Pakistan of Rs. 7 crore by informal routes. Through alternative routes it cost more than $17 \%$ due to without formal trade. If Pakistan will import this equipment from third country cost will further rise by $35 \%$. Conflicts caused lost in trade, it effects the GDP growth.

Trade normalization reduces conflicts and promotes peace: Paul Samuelson in 1948 related the productive and non-productive activities with butter and guns. Nazi Germany further elaborated it. Government made to increases its expenditure more on military (guns), due to more expenditure on military public expenditure used to be declined in both production and consumption (butter). Classical assumed that, countries gets benefits from productive expenditures rather than non-productive expenditure. Same condition is applied to India and Pakistan. Both countries use there more resources on defense rather than on making better relations with each other's.

Peace is created through promotion of trade and peace in both countries creates the positive influence in Asia region. This reduces the conflicts and increases the economic consideration. Both countries know about the opportunity cost of conflicts, loss is suffered by less trade volume. Mutual issues regarding the border and Kashmir will be resolved through the dialogues. History shows that conflicts among the countries are made better through trade. US congress initiated the project of qualifying industrial zone. This zone was established in 1999 for Israel and Jordan and in 2004 for Jordan and Egypt. The purpose was to increase the import of Israel via US. In this project it was mentioned that the products that are traded become duty free if they comprise of some quantity of inputs that are imported from Israel. By this economic activity stability and peace has been encouraged. Pakistan and India also need such qualifying industrial zone types programs to increase cooperation and regional integration. Strong trade relations among the China and Japan lagged behind the political conflicts. By normalization trade between Pakistan and India beneficial for economic benefits. Political tension and rivalry between both countries creates hurdle for normalization of trade. Pakistan imported 1936 products from India after 2011. Pakistan trade with India more than $85 \%$ as compared to 2011. During the 2012, Pakistan export to India is increased by $66 \%$ and India export to Pakistan increased by $16 \%$.

India removes the Foreign Direct Investment restriction on Pakistan after 2011. Pakistan also trade with India in services and in information technology. Through trade with India not only limit the inflation also strength the economies of both countries. Pakistan and India signed the agreements on custom procedures, product standard and conflicts resolution. Border check post between Attari and Wagah facilitated with modern facilities and allowed to cross more trucks on daily basis. India removed restrictions on $30 \%$ goods and allowed for trading.

Through trade liberalization in both countries get the cheap goods and their choice for goods expanded. Both countries need to create cooperation for peace and security in region. If by giving the MFN status to each other, greater cooperation leads to economic gain in Pakistan and India.

Both countries cooperate in IT, science and technology, R\&D, started joint economic projects. This will enhance the domestic industry production and increase the economic growth. By mutual collaboration, both countries achieved the specialization in subsectors of their economies. Bilateral trade creates the strength for both countries to reduce the impact of global financial shocks. Economic relations cannot resume until the resolution of political disputes. Business communities created the pressure by lobbing and support the peaceful bilateral political relations.

Keeping trust and with more connection declined the border conflicts. Fewer restrictions on trade automatically enhance the trade and increase the mutual cooperation. While investing in infrastructure and intra trade increase the cooperation among them.

According to approximation, both countries have ability to grow bilateral trade to $\$ 20$ billion. It is necessary for Pakistan to trade with India to become a trade hub. The historical trade routes for northsouth and east-west gives the sources for growth in coming years. By mitigating the conflicts, Pakistan gains the investment from India. India invests about $\$ 14$ billion in neighboring countries. Investment in mainly done for infrastructure and manufacturing sector. India's investment GDP is twice as compared to Pakistan, India is able to invest about $\$ 1.3$ trillion and Pakistan is able to invest only $\$ 18$ billion. Indus basin is important joint collaboration of economic unit.

Trade barriers in India Pakistan trade: Pakistan and India trade relations ships are not at good pace since independence. Political issues between both countries create trade hurdles. Bilateral trade between them is developing peace in Asia. They realized the potential in bilateral trade enhance the economic progress. India and Pakistan are members of World Trade Organization and signatories of General Agreement of Trade and Tariff (GATT). Both countries have border and political conflicts and they are not execute WTO obligations. In 1996 India gave the Most Favourite Nation (MFN) status to Pakistan, Pakistan not gave MFN status to India as reciprocity. At that time Pakistan only increase its positive list of goods and Pakistan reduce the unilateral non-trade 
barriers for India trade increase the better trade capacities. Economic cooperation between them in long run help full to decree the defensive issues. Pakistan has already traded with India in 1936 products so it will not be problematic for Pakistan to giving MFN status India [14]. Through direct bilateral trade increase the revenue and cooperation among the South Asian Region. Flexibility between the joint agreements perk up the economic corporation. Peace and stability in this region worsen due to their dispute. Strong strategies are required to resolve the disputes such as Kahmir, Siachin and border terrorism issues.

Countries are not sufficient in production of all commodities. Pakistan major export earnings are come from textile sector. Pakistan cotton crop is growing on high scale. In Pakistan $48 \%$ of people are working in textile sector. India is big economy. Pakistan gets the access to India market gets, earns more. Pakistan exports the leather product on large scale. But India is not importing it from Pakistan due to import barriers. Pakistan imports the tea from Kenya. It becomes less expensive if it import from India. Wheat, sugar and iron are import from Australia, US and Indonesia in Pakistan. Also Pakistan not imports the automobile spare parts from India. Pakistan export agriculture products, sports items, carpets and textile to countries other than India [15-18].

Pakistan trade with other countries more than India. Different trade constraint and barriers reduce the export. India has imposed the high tariffs on Pakistan's imports especially on leather and textile.

Politicians of both countries creates hurdle and conflicts and they creates hurdles in economics collaboration. By creating trust with each other's border disputes and conflicts are solved. By lowering the trade restriction in trade, the trade relations between India and Pakistan gets better. This give the way to businessman and trade related companies to increase the trade and they would enforce the politicians to sustain the bilateral trade between India and Pakistan. Both countries government should make the priorities about the trade and they realize the peace and stability obtained through bilateral trade. The actual and potential trade difference between India and Pakistan is due under SAFTA sensitive list approach [19].

\section{Conclusion}

Trade between the India and Pakistan creates peace and harmony among them. Trade develops the mutual understanding economic interests and reduces the chances of war among them. Strong economic bindings between India and Pakistan harmonized their disputes and border conflicts. Bilateral trade is essential for reduction of tension. Bilateral trade is enhanced by reducing the trade barriers, easy cross border movement of goods, services, creating a fair competition, implementation of agreements through proper mechanism and customs procedure more transparent and simple. Direct trade with India reduces the transaction cost. Trade normalization lead to economic cooperation, less domestic prices, gets economies of scale and market size becomes expanded.

Trade framework is made independently with political pressure. Both countries discuss the hurdles and problems related to trade and remove such obstacles. Bilateral trade and economic cooperation is enhanced by resolving the territorial conflicts. By making the more business and commercial links, trust and willingness to cooperate with each other is way to get the peace and stability. Trade is soft and positive way to reduce the conflicts.

\section{Recommendations}

- In order to enhance the trade their political as well as military conflicts should resolve. This promoted regional integration.

- Joint investment venture in infrastructure are prompted and takes the efforts to enhance the trade. Rationalizing the trade barriers that restraint flow of trade goods.

- Seasonal shortage of agricultural products takes place in both countries. Special trade agreements are made on such case and gets the benefit in form of low price rather than high price goods due shortage.

- Trade in services has large potential for India and Pakistan. Pakistan can import the IT related services from India. This will upgrade the service sector in Pakistan.

- Indus basin is important joint collaboration of economic unit. According to estimate if both countries jointly work there they will able to produce the 8000 MW. Regional integration is boasted by reducing conflicts. Cheap energy sources are exported through Central Asia, Iran and Middle East.

\section{References}

1. Cali M, Miaari SH (2014) Trade, employment and conflict: Evidence from the Second Intifada. The Institute of Development Studies - at the University of Sussex-Falmer-Brighton Working Paper 186.

2. Martin P, Thierry M, Theoing M (2007) Make Trade Not War? Review of Economic Studies 75: 865-900.

3. Lee JW, Pyun H (2009) Does Trade Integration Contribute to Peace? Working Paper Series on Regional Economic Integration No. 24.

4. Brutger R, Wright AL (2015) The Costs of Conflict: Border Disputes and Trade Diversion. Department of Politics, 130 Corwin Hall, Princeton NJ.

5. Sab A (2014) Economic Impact of selected conflicts in the Middle East: What can we learn from the Past? International Monetary Fund.

6. Polachek C, Seigile C (2006) Trade, Peace and Democracy: An Analysis of Dyadic Dispute. Discussion Paper No. 2170.

7. Taneja N (2013) Enhancing India-Pakistan Trade. Indian Council for Research on International Economics Relations, New American foundation, pp: 1-34

8. Khan A (2009) India-Pakistan Trade: A Road Map for enhancing the Economic relations policy. Brief, pp: 9-15.

9. Naqvi Z (2009) Pakistan-India Trade Potential and Issues. The Lahore Journa of Economics 14: 171-201.

10. Bose S (2004) Kashmir, roots of conflicts: paths to peace. In: Walter L (ed.) Voices of Terror. Reed Press, New York, USA

11. Bose S (2001) Kashmir at the Crossroads: Problems and Possibilities. Security Dialogue 32: 41-64.

12. Nawaz S, Guruswamy M (2014) India and Pakistan: The Opportunity Cost of Conflict. Atlantic council.

13. Ali M, Noreen M, Rahman A (2015) Pakistan-India Relations: Peace through bilateral trade. Developing country studies.

14. Qamar A (2005) Trade between India and Pakistan: Potential Items and the MFN Status. SBP Research Bulletin 1: 45-58.

15. Ravi P (2013) A Road to Peace? Prospects of Developing Greater IndoPakistan Trade. International Security and Cooperation. Leland Stanford Junior University.

16. Brown O (2005) EU Trade Policy and Conflicts. Published by the Internationa Institute for Sustainable Development, Canada.

17. Mehta PS (2013) Building peace through trade: The Future of India-Pakistan Trade \& Economic Relations. CUTS International 99: 3-49.

18. Mehta PS (2012) Trade Relationship between Pakistan and India. Pakistan Institute of legislation Development and Transparency.

19. Smith CJ (2008) Trade and Conflict: An Inverse Relationship? Eastern Michigan University pp: 1-17. 